\title{
Removal of Used Engine Oil by a Novel Lab Scale Bioreactor
}

\author{
Dhanya V.
}

Department of Biotechnology, Al-Ameen College, Edathala, Aluva, Ernakulam, Kerala - 683564, India.

\begin{abstract}
Engine oil is considered as one of the most important classes of environmental contaminant. Removal of dumped waste engine oil is a challenging task because of its persistent nature in the ecosystem. Biodegradation of used engine oil with microbial consortium offers a very promising approach in terms of cost-effectiveness and elimination of secondary pollutants. This study investigates the efficiency of a formulated bacterial consortium in engine oil biodegradation. Four novel bacterial isolates Enterobacter aerogenes, Raoultella sp, Bacillus megaterium and Bacillus cereus were selected by soil enrichment technique. The newly isolated bacterial strain was identified by $16 \mathrm{~s}$ rDNA sequencing as Bacillus cereus strain VCRC B540. Individual cultures degrade $5 \mathrm{ml}$ of used engine oil in 15 days. A polyurethane bioreactor adsorbed with the formulated bacterial consortium was very effective in degrading $75 \%$ of used engine oil at a pH 7 within 10 days. Degradation of used engine by the bacterial strains was analyzed by Fourier Transform Infrared Spectroscopy (FT/IR). Based on the available information, this is the first report discussing the engine oil biodegradation potential of a polyurethane bioreactor and the efficiency of the formulated consortium can be used for the better removal of used engine oil from contaminated sites and different effluents.

Keywords: Biodegradation, Fourier Transform Infrared Spectroscopy, Microbial consortium, Polyurethane bioreactor, Used engine oil
\end{abstract}

*Correspondence: dhanusree016@gmail.com; +91-9495559439

(Received: December 26, 2019; accepted: February 03, 2020)

Citation: Dhanya V., Removal of Used Engine Oil by a Novel Lab Scale Bioreactor, J. Pure Appl. Microbiol., 2020; 14(1):509-516. https://doi.org/10.22207/JPAM.14.1.53

(C) The Author(s) 2020. Open Access. This article is distributed under the terms of the Creative Commons Attribution 4.0 International License which permits unrestricted use, sharing, distribution, and reproduction in any medium, provided you give appropriate credit to the original author(s) and the source, provide a link to the Creative Commons license, and indicate if changes were made. 


\section{INTRODUCTION}

Engine oils are mixture of lubricant oil and additives. Lubricating oil is a petroleum product contains long chain saturated hydrocarbons, carcinogenic polycyclic aromatic hydrocarbons and cyclic alkanes. The increased transportation causes an increase demand for engine oil. One billion gallons of waste engine oil are generated during recent years from automobile and mechanical workshops. A few of this amount is recycled and most is disposed off by dumping ${ }^{1}$. The illegal dumping of used engine oil will leads to dangerous environmental pollution and become potential threat to human, animals and other vegetation's. Therefore, there is a need for appropriate recycling of dumped engine oil to avoid the dangerous threats towards the environment. Many mechanical methods are used now days to remove the dumped engine oil. But these methods are not so much efficient. These methods do not remove the waste but relocate the problems.

Biodegradation is the most suitable method of choice due to its cost effectiveness and wide acceptability. Biodegradation process uses the application of microorganisms and their enzymes to remove the pollutants completely. Biodegradation exploit the degradative capacity of microorganisms to transform toxic pollutants to less toxic components. Such efforts would depend on the availability of petrophilic microorganisms with capacity to degrade the broad array of components in the contaminant. Many research works reported the presence of engine oil and waste engine oil degrading strains of genera such as Acinetobacter, Achromobacter, Arthrobacter, Flavobacterium, and Pseudomonas ${ }^{2,3,4,5,6,7}$. Ahda et al. ${ }^{8}$ reported the isolation of 13 bacterial strains which have the capacity to degrade lubricant oil and the isolate D4 showed the maximum degradation efficiency. Parikh et al., ${ }^{9}$ isolated Pseudomonas aeruginosa DP-1 which showed 68 $\%$ engine oil degradation capacity in 32 days of incubation.

Individual strains are capable of degrading only some components present in used engine oil. So formulate consortium is better for the effective removal of different components in engine oil. So the present study focused on the formulation of a bacterial consortium for the effective removal of used engine oil and also focused on the application of a polyurethane based bioreactor for the degradation of engine oil in a better way.

\section{MATERIALS AND METHODS Soil sample}

Soil sample contaminated with used engine oil was collected from automobile garage located near Edathala, Ernakulam, Kerala. The sample was collected from a depth of $15 \mathrm{~cm}$ after removing the surface layer and transferred to the laboratory and kept at $4^{\circ} \mathrm{C}$ until for the isolation. The soil sample was blackish in color.

\section{Composition of medium}

Defined mineral salt (MS) medium with $1 \mathrm{~g} \mathrm{KH} \mathrm{PO}_{4}, 1 \mathrm{~g}\left(\mathrm{NH}_{4}\right)_{2} \mathrm{SO}_{4}, 0.5 \mathrm{~g} \mathrm{Mg} \mathrm{SO} \cdot 7 \mathrm{H}_{2} \mathrm{O}$ and $0.001 \mathrm{~g} \mathrm{CaCl}_{2}$ in 1 litre of the distilled water was used as the basal medium. $1000 \mathrm{ml}$ of MS medium with $5 \mathrm{ml}$ of used engine oil (UEO) as the only sole carbon source at a pH of 7 was used as the sample in the present study. The engine oil was used only after filtration to remove impurities. The medium was sterilized at $121^{\circ} \mathrm{C}$ for $20 \mathrm{~min}$ and the oil was added after sterilization.

\section{Isolation of UEO degrading bacterial strains}

UEO degrading bacteria were isolated from oil contaminated soil by an enrichment culture technique using UEO as the only carbon source. BTXP degrading bacterial strains Enterobacter aerogenes SBS1: KC758848, Raoultella sp. SBS2: KC758849 and Bacillus megaterium SBS3: KC758850 isolated during previous study was used as the primary members during biodegradation studies $10.1 \mathrm{~g}$ of oil contaminated soil was added to sterile MS medium and supplemented with 250 $\mu \mathrm{l}$ of UEO in $250 \mathrm{ml}$ Erlenmeyer flask. The sample was incubated at $37^{\circ} \mathrm{C}$ for 5 days at $150 \mathrm{rpm}$. Later $1 \mathrm{ml}$ of enriched media was transferred into freshly prepared MS medium with $500 \mu \mathrm{I}$ UEO. Incubate the medium for another 5 days at the same condition. The same procedure was repeated with $1 \mathrm{ml} \mathrm{UEO}$. After these three successive transfers, collect the pellets from the medium and plated onto sterile mineral salt oil medium with 1 mI UEO. The plates were incubated at $37^{\circ} \mathrm{C}$. The bacterial colonies able to grow by utilizing UEO as carbon source were selected and used for the degradation studies.

\section{Screening of UEO degrading bacterial strains}

Screening of UEO degrading bacterial isolates were done on the basis of bacterial growth 
in $100 \mathrm{ml} \mathrm{MS}$-oil medium with $3 \mathrm{ml}$ used engine oil and FT/IR analysis. The bacterial growth was evaluated by measuring the optical density at 540 nm using UV-Visible spectroscopy. Un-inoculated MS-oil medium was used as a blank to adjust the spectrophotometer reading to zero. The strain which shown superior growth after 10 days of incubation and structural changes in FT/IR spectra were selected for the formulation of bacterial consortium for the better degradation of used engine oil from the medium.

\section{Biodegradation studies}

$5 \mathrm{ml}$ of used engine oil was added to $1000 \mathrm{ml} \mathrm{MS}$ medium and inoculated with individual isolates with 0.5 OD concentrations at $540 \mathrm{~nm}$. The biodegradation was continued for about 15 days and removed the cells by centrifugation at $10,000 \mathrm{rpm}$ for 10 minutes. The supernatant was subjected to FT/IR for the analysis of biodegradation efficiency of individual bacterial isolates.

\section{Identification of selected bacterial strain}

Identification of isolated strain screened through soil enrichment technique was done mainly through $16 \mathrm{~S}$ rDNA sequencing analysis using the forward primer sequence (5'-AGA GTT TGA TCM TGGCTC-3') and the reverse sequence $\left(5^{\prime} \text {-AAG GAGGTG WTC CAR CC-3' }\right)^{10}$. PCR products were sequenced at Scigenome labs, Pvt Ltd, Cochin, Kerala.

\section{Phylogenetic analysis of UEO degrading bacterial} strains

Sequences of UEO degrading isolates were aligned and phylogenetic analysis was performed using Clustal-Omega programe.

\section{Microbial consortia formulation}

One loopful of Enterobacter aerogene, Raoultella sp, Bacillus megaterium and the selected bacterial strain through soil enrichment was individually inoculated to $50 \mathrm{ml}$ of nutrient medium supplemented with $3 \mathrm{ml}$ of used engine oil were incubated overnight at $37^{\circ} \mathrm{C}$ at $150 \mathrm{rpm}$. From the culture the cells were harvested by centrifugation. The pellets were collected and suspended in physiological saline $(0.85 \% \mathrm{NaCl})$ to obtain the inoculum of $1.0 D$ concentration at 540 $\mathrm{nm}$. The microbial consortium for biodegradation studies was formulated by mixing equal proportions ie, $5 \mathrm{ml}$ of each culture.

\section{Bioreactor based biodegradation studies}

The laboratory scale bioreactor constructed using polyurethane (PU) tubular coil and a peristaltic pump for previous biodegradation studies was used for the present study. The polyurethane based bioreactor was selected because of its better mechanical strength to microbial growth and with respect to its possible industrial applications. The specification of PU coil was with $8 \mathrm{~mm}$ internal diameter, $5 \mathrm{~m}$ total length and $120-125 \mathrm{ml}$ working volume (Fig.1). A steel wire having $6 \mathrm{~m}$ length and $4 \mathrm{~mm}$ thickness inserted in to the PU tubular coil. One end of the wire was sharpened and crooked to rub the smooth inner surface of the PU coil. The other end of this steel wire was connected to a power tool and rotated the wire through the inner surface of the PU coil to make scratches. The saline suspension of bacterial consortium was passed through the reactor and flow rate through the reactor was controlled by the peristaltic pump (Pharmacia). The conical flask containing bacterial-saline suspension was placed on the top and further connected to the inlet of peristaltic pump with a sterile tube. When the pump was switched-on the bacterial-saline suspension was driven through the sterile tube towards the inlet of the pump. The output of the peristaltic pump connected to the PU coil inlet. The suspension was driven through the pump to the PU coil unit at the selected flow rate of $1 \mathrm{ml} /$ min for the adsorption of the consortium onto the rough inner surface of the PU coil. $1000 \mathrm{ml}$ of mineral salt medium with $10 \mathrm{ml}$ UEO was run through the consortium adsorbed PU coil at a speed of $1 \mathrm{ml} / \mathrm{min}$ for the bacterial degradation of used engine oil present in the medium. Further the output of the PU coil unit was connected to a conical flask for the collection of bacterial treated sample completely. After collection, the treated sample was again run through the coil and the process was repeated for 10 days. After 10 days, biodegraded sample was centrifuged at $10,000 \mathrm{rpm}$ for the removal of bacterial cells. The supernatant was extracted with diethyl ether. After extraction the supernatant was subjected to FT/ IR for the analysis of biodegradation efficiency of formulated bacterial consortium.

Biodegradation analysis of UEO

The biodegradation efficiency of constructed bioreactor was studied by calculating 
the percentage reduction of engine oil present in the medium and was done spectroscopically. The control sample and the biodegraded samples at different time intervals of incubation ie., 2,4,6,8 and 10 days were scanned between $200-800 \mathrm{~nm}$ using Hitachi spectrophotometer. The \% removal of BTXP at different flow rates were calculated as,

$\%$ removal of BTXP $=\quad$ [Initial OD at $391 \mathrm{~nm}$ Final OD at $391 \mathrm{~nm} /$ Initial OD at $391 \mathrm{~nm}$ ] X 100

where the $\lambda$ max of control MS-UEO medium was used as the initial OD.

\section{RESULT AND DISCUSSION}

Biodegradation is the process in which different types of microorganisms convert the toxic pollutants to simple less toxic components that are eco-friendly in nature ${ }^{11}$. Many studies $12,13,14,15$ revealed the participation of bacteria in the degradation of components present in used engine oil.

Isolation and screening of oil degrading bacteria The bacterial strains were selected based on their capability to grow on used engine oil and used it as the energy and carbon source. Four bacterial strains were isolated and from these only one strain (Sample 4) was selected as the potent degrader of UEO for further studies. The selected strain showed superior growth in MS-oil medium (Fig. 2) and the degradation capacity of the selected strain was confirmed by FT/IR analysis. The bacterial strains Enterobacter aerogenes, Raoultella sp. and Bacillus megaterium were also showed superior growth in oil containing media and the degradation capacities were confirmed through FT/IR analysis. As shown in Fig. 2 the bacterial isolates Enterobacter aerogenes, Raoultella sp, Bacillus megaterium and Sample 4 showed superior growth. The OD at $540 \mathrm{~nm}$ of these four isolates was $0.44,0.441,0.443$ and 0.445 respectively.

\section{Biodegradation studies}

Many researchers revealed that microbial inoculum with particular cell densities were essential for the success of biodegradation of toxic chemicals. In this study a standardized inoculum with 0.5 absorbance at $540 \mathrm{~nm}$ was used successfully to determine the effectiveness of each strain during biodegradation.
During the biodegradation of used engine oil using bacterial consortium, the determination of individual compound degradation is essential. When compared with the un-inoculated control engine oil sample (Fig. 3) FT/IR analysis of the mineral salt engine oil medium individually inoculated with Enterobacter aerogenes, Raoultella sp, Bacillus megaterium and Sample 4 (Fig. 4(A-D) showed slight shift or disappearance of specific bands represents the components in engine oil within 15 days. These changes indicated the structural changes in the functional groups of different components presents in used engine oil and the shift or disappearance of corresponding vibrations indicated the participation of individual bacterial strains on the degradation of used engine oil.

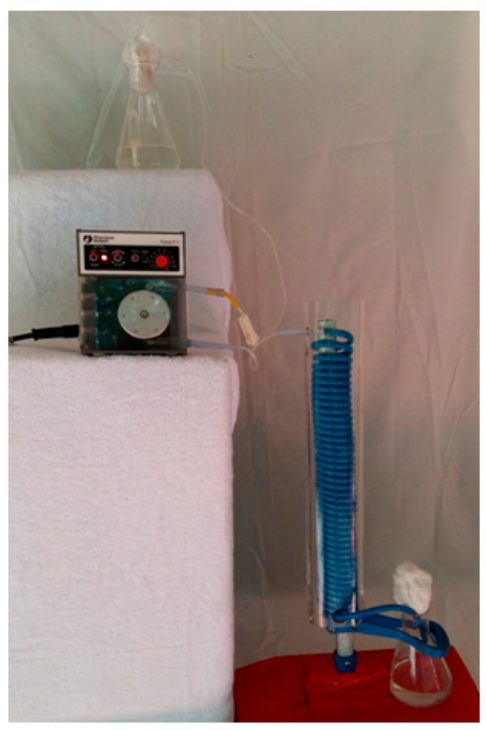

Fig. 1. Working condition of PU based bioreactor

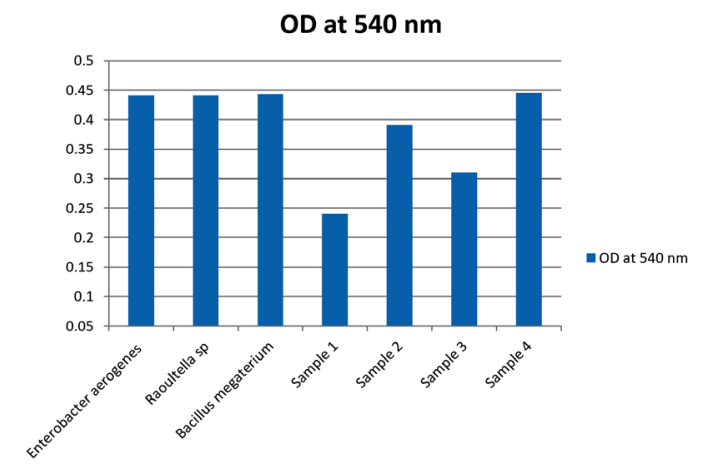

Fig. 2. Growth potential of the selected bacterial strains 


\section{Identification of selected bacterial strain}

The bacterial strain showed superior growth in MS-Oil medium and effective degradation od used engine oil was sent to Scigenome labs, Pvt Ltd, Cochin, Kerala, to amplify and sequence $16 \mathrm{~S}$ rDNA gene for identification using the forward primer sequence (5'-AGA GTT TGA TCM TGG CTC-3') and the reverse sequence (5'-AAG GAG GTG WTC CAR CC-3'). The final concentration of the reagents was $1 \mathrm{mM} \mathrm{MgCl} 2,200 \mu \mathrm{M}$ dNTP, 100 pmol primers and 50 ng DNA ${ }^{16}$. Polymerase Chain Reaction (PCR) was carried out in MycyclerTM (BioRad, USA) with the following PCR Cycle: one cycle at $94^{\circ} \mathrm{C}$ for $2 \mathrm{~min}$, followed by 35 cycles at $94^{\circ} \mathrm{C}$ for $1 \mathrm{~min}, 55^{\circ} \mathrm{C}$ for $1 \mathrm{~min}, 72^{\circ} \mathrm{C}$ for $2 \mathrm{~min}$, followed by final $2 \mathrm{~min}$ incubation at $72^{\circ} \mathrm{C}$ and the PCR products were sequenced. The sequence similarity was analysed by sequences available in the National Center for Biotechnology Information (NCBI) database using BLAST (Basic Local Alignment Search Tool) analysis and the strain was identified on the basis of the best match in the database. The $1500 \mathrm{bp}$ amplicon in 1\% agarose was identified as Bacillus cereus.

Phylogenetic analysis of UEO degrading strains

Genetic diversity among the UEO degrading strains were studied using $16 \mathrm{~S}$ rDNA sequences and the sequence obtained for sample 4 ie, Bacillus cereus was compared with the highest score reference sequences from the NCBI GenBank database. The phylogenetic tree was constructed for illustrating the possible relationships among the four isolates (Fig. 5). Phylogenetic analysis was conducted in Clustal-Omega programe. The isolates Bacillus megaterium and Bacillus cereus were clustered together with high similarities and the isolates Enterobacter aerogenes and Raoultella

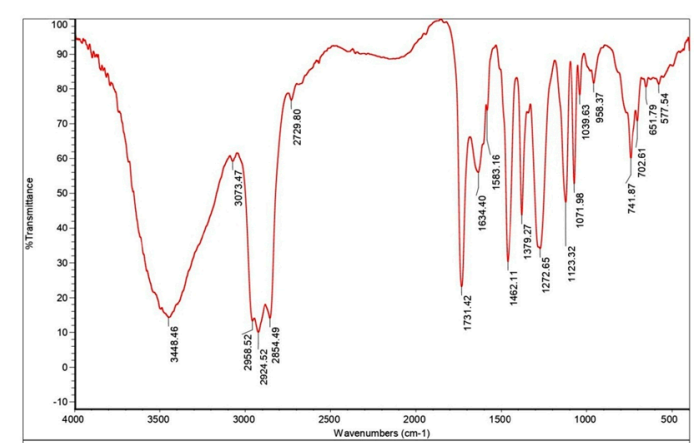

Fig. 3. FT/IR of un-inoculated Mineral salt-used engine oil (MS-OIL) medium sp were clustered together.

\section{Biodegradation efficiency of bioreactor}

The UV-Vis spectroscopic analysis indicated that the control MS-UEO medium showed maximum absorbance of 2.88 at 391 $\mathrm{nm}$, which considered as the initial OD for calculating the \% degradation of engine oil. The decrease in the absorbance at $391 \mathrm{~nm}$ with different incubation time indicated the progressive degradation of engine oil present in the medium (Table 1). A significant decrease was occurring after 10 days of incubation and the \% degradation of engine oil was calculated as 75.312.

The ether extracted supernatant of treated Mineral Salt oil medium using the consortium adsorbed PU based bioreactor was analysed by FT/IR after 10 days of incubation period (Fig. 6). When compared with the FT/IR spectrum of uninoculated control medium (Fig. $3)$, the FT/IR spectrum of treated sample showed the absence of many of the peaks present in the control sample. It also showed the decrease in the sharpness of peak at $3448.46 \mathrm{~cm}^{-1}$ indicating the presence of peptide component resulting from $\mathrm{N}-\mathrm{H}$ stretching and between $1700-1400 \mathrm{~cm}^{-1}$ range shows the stretching of $\mathrm{C}=\mathrm{C}$. The reduction in peak sharpness is a strong indication for degradation, as it shows significant reduction in aliphatic compounds present in the used engine oil.

FT/IR spectroscopy can be a very useful preliminary analytical technique in distinguishing the degradation efficiency of microorganisms. So the present study selects FT/IR as an appropriate approach to detect the biodegradation efficiency of bacterial strains as individuals and as consortium. Bacterial degradation of used engine oil has been shown to occur by the attack on the aliphatic and aromatic functional groups present in the oil. The present study reported the effective degradation of used engine oil from the medium using a consortium adsorbed PU based bioreactor within 10 days. The structural novelty of the lab scale bioreactor helps the researches to do the biodegradation studies with in a small space and exhibit low and fast rate removal of toxic oil contents from the polluted sites.

Many researchers reported the isolation of microorganisms for the biodegradation of components in used engine oil. The engine oil degradation ability of 18 fungal isolates was 
reported by Husaini et al., ${ }^{17}$. Penicillium species (P1) completely degrades the n-alkanes in the used motor oil after 2 months of incubation. Su et al., ${ }^{18}$ demonstrated the motor-oil-degrading potential of an indigenous Pseudomonas aeruginosa SU-1 bacterial strain was found to have the capacity to degrade engine oil effectively. Bhattacharya et al., ${ }^{14}$ reported that a newly isolated Ochrobactrum sp. C1 could grow with waste lubricants. An efficient bacterial consortium A2457: encompassing Stenotrophomonas maltophilia, Bacillus pumilus, and $B$. cereus was formulated by
Larik et al., ${ }^{19}$ for the degradation of used engine oil. Salam 7 established the extensive degradation ability of aromatic, aliphatic and branched alkane components of two Pseudomonas aeruginosa strains RM1 and SK1 on waste engine oil. Researchers usually suggested the application of microbial consortium for the complete degradation of different components since the constituents of engine oil differ in their solubility, volatility, and susceptibility to biodegradation, and in contrast, the essential sets of enzymes cannot be present in a single microbial strain.
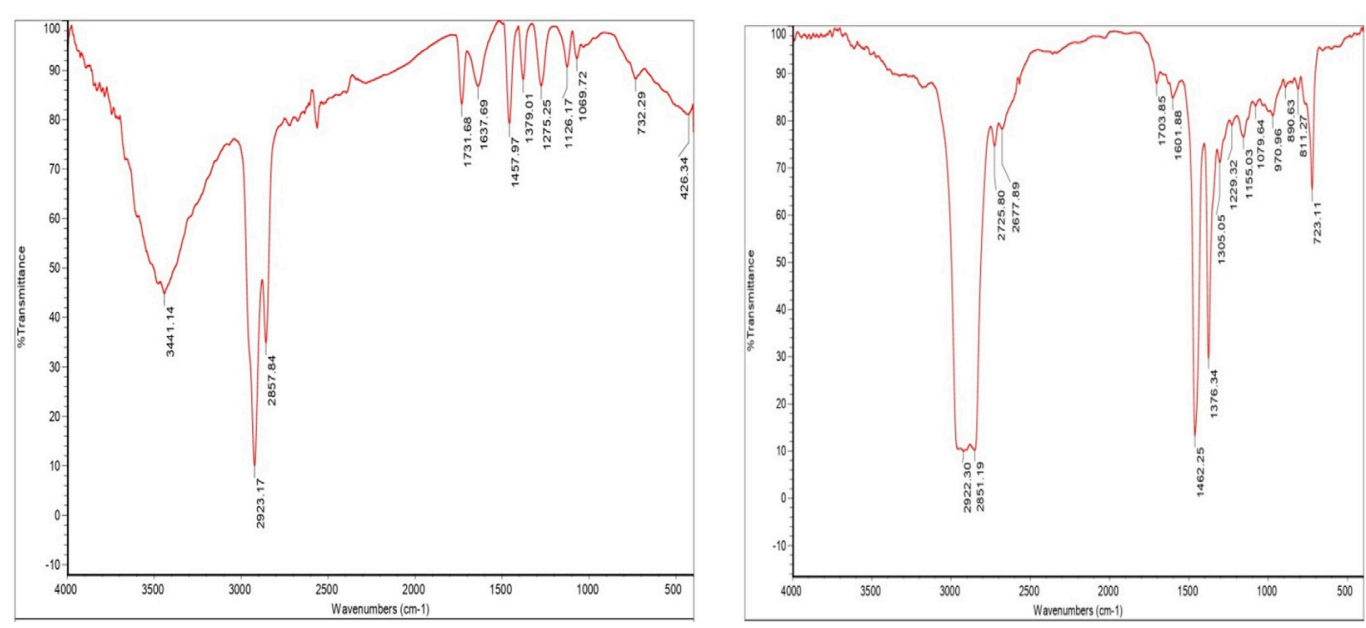

A

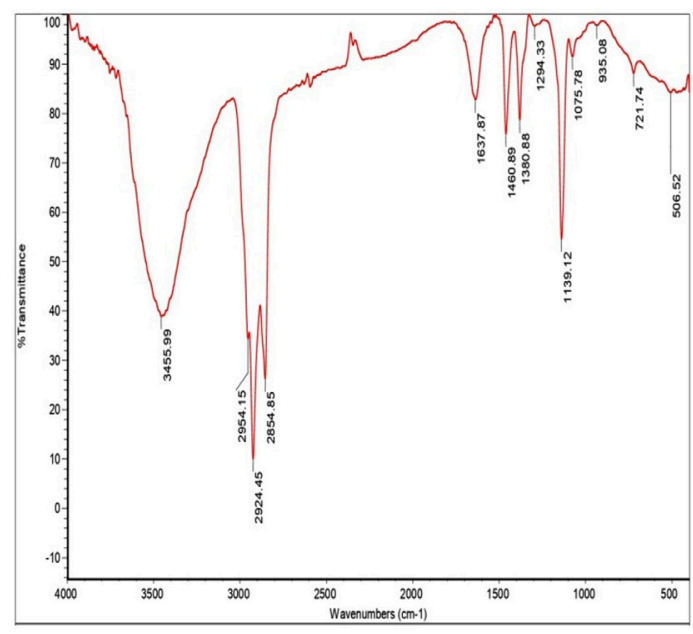

$\mathrm{C}$

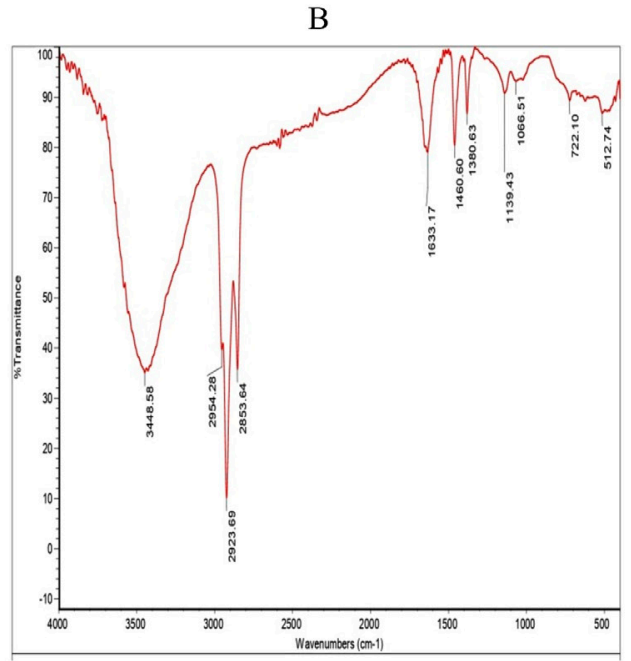

$\mathrm{D}$

Fig. 4 (A-D). FT/IR spectra of biodegraded used engine oil by individual isolates. A: Enterobacter aerogenes, B: Raoultella sp, C: Bacillus megaterium, D: Bacillus cereus 
Table 1. Percentage degradation of used engine oil with consortium adsorbed bioreactor at different incubation time

\begin{tabular}{lcccccc}
\hline $\begin{array}{l}\text { Wave length } \\
391 \mathrm{~nm}\end{array}$ & $0 \mathrm{hr}$ & 2 days & 4 days & 6 days & 8 days & 10 days \\
\hline $\begin{array}{l}\text { Absorption at } 391 \mathrm{~nm} \\
\text { \% degradation of used engine oil }\end{array}$ & 2.88 & 2.537 & 2.115 & 1.512 & 0.917 & 0.711 \\
& & 11.909 & 26.562 & 47.50 & 68.159 & 75.312 \\
\hline
\end{tabular}
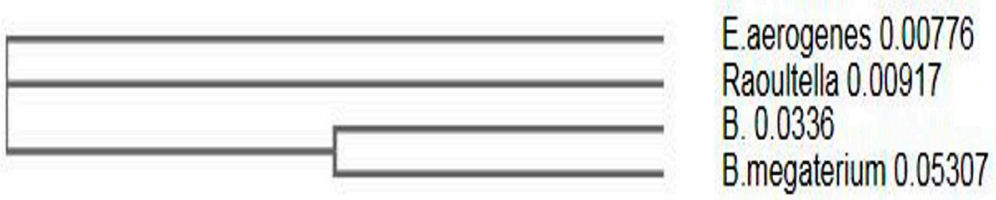

Fig. 5. Phylogenetic tree expressing the relationships among UEO degrading isolates based on the $16 S$ rDNA sequences

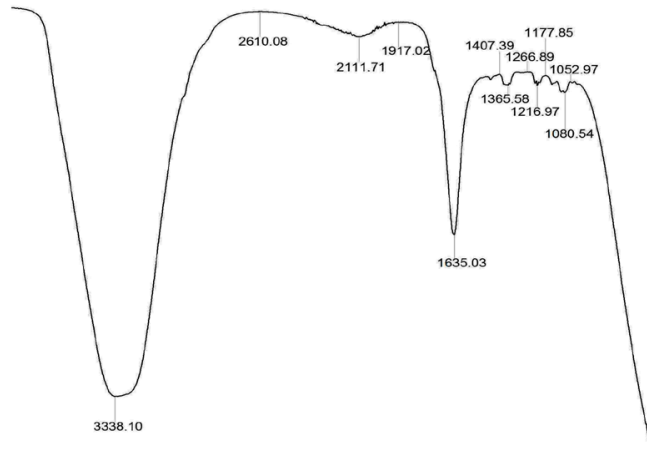

Fig. 6. FT/IR spectra of biodegraded used engine oil by formulated bacterial consortium adsorbed PU

Additional investigation through scanning electron microscopy will gives more information's about the adsorption capacity of the bacterial consortium onto the inner surface of PU coil. Further molecular studies along with GC-MS (Gas chromatography-Mass spectrometry) and NMR (Nuclear magnetic resonance spectroscopy) analysis of the metabolites may throw light into the actual pathway followed for the degradation of used engine oil.

\section{CONCLUSION}

Biodegradation of engine oil with multicomponents was studied by using individual pure cultures and bacterial consortium formulated with four bacterial strains Enterobacter aerogenes, Raoultella sp, Bacillus megaterium and Bacillus cereus. The results showed that the polyurethane based bioreactor adsorbed with formulated consortium is more effective in the biodegradation of used engine oil and is occur within 10 days. Therefore, the lab scale bioreactor and the formulated bacterial consortium used in this study could be relevant in the abatement of environment that may be contaminated with engine oil.

\section{ACKNOWLEDGMENTS}

The authors like to express thanks to Biotechnology department, Al- Ameen College.

\section{FUNDING}

None.

\section{DATA AVAILABILITY}

All datasets generated or analyzed during this study are included in the manuscript.

\section{ETHICS STATEMENT}

The article does not contain any studies with human participants or animals

\section{REFERENCES}

1. Kalyani K.A., Pandey K.K. Waste to energy status in India: a short review. Renew Sustain Energy Rev, 2014; 31: 113-120. https://doi.org/10.1016/j. rser.2013.11.020

2. Adelowo O.O., Alagbe S.O., Ayandele A.A. Time dependent stability of used engine oil degradation by cultures of Pseudomonas fragi and Achromobacter aerogenes. Afr J Biotechnol, 2006; 5 (24): 2476-2479.

3. Mandri T., Lin J. Isolation and characterization of engine 
oil degrading indigenous microorganisms in KwazuluNatal, South Africa. Afr J Biotechnol, 2007; 6 (1): 23-27.

4. Bagherzadeh-Namazi A., Shojaosadati S.A., HashemiNajafabadi S. Biodegradation of used engine oil using mixed and isolated cultures. Int J Environ Res, 2008; 2: 431-440.

5. Basuki W., Syahputra K., Suryani A.T Pradipta I. Biodegradation of used engine oil by Acinetobacter junii TBC 1.2. Indones J Biotechnol, 2011; 16 (2): 132138. https://doi.org/10.22146/ijbiotech.16374

6. Obayori O.S., Salam L.B., Ogunwumi O.S. Biodegradation of fresh and used engine oils by Pseudomonas aeruginosa LP5. J Bioremed Biodeg, 2014; 5 (1): 213. https://doi.org/10.4172/2155-6199.1000213

7. Salam L.M. Metabolism of waste engine oil by Pseudomonas species. 3 Biotech, 2016; 6 (1): 98-107. https://doi.org/10.1007/s13205-016-0419-5

8. Ahda Y., Azhar M., Fitri L., Afnida A., Adha G.S., Alifa W.N., Handayani D., Putri D.H., Irdawati I., Chatri M. Biodegradation Capability of Some Bacteria Isolates to Use Lubricant Oil in Vitro. IOP Conf Ser: Mater Sci Eng, 2018; 335: 1-6. https://doi.org/10.1088/1757899X/335/1/012134

9. Parikh D.R., Tipre D.R., Nayak N.S., Dave S.R. 2018. Degradation of Discarded used Engine Oil by Pseudomonas aeruginosa DP-1 and Its Optimization. Int J Curr Microbiol App Sci, 7 (04): 2224-2229. https:// doi.org/10.20546/ijcmas.2018.704.253

10. Vijayan D., Kochupurackal J., Abraham A., Nair I.C. Microbial consortia formulation for the effective biodegradation of benzene, toluene, xylene and phenol. J Microbiol Biotechnol Food Sci, 2014; 3 (6): 457- 462.

11. Margesin R., Moertelmaiyer C., Mair J. Low-temperature biodegradation of petroleum hydrocarbons ( $n$-alkanes, phenol, anthracene, pyrene) by four Actinobacterial strains. Int Biodeterio Biodeg, 2013; 84: 185-191. https://doi.org/10.1016/j.ibiod.2012.05.004
12. Abioye P.O., Agamuthu P., Aziz A.R. Biodegradation of used motor oil in soil amended with organic wastes. Biotechnol Res Int, 2012; 1-8. https://doi. org/10.1155/2012/587041

13. Dadrasnia A., Ismail S. Biosurfactant production by Bacillus salmalaya for lubricating oil solubilization and biodegradation. Int J Environ Res Public Health, 2015; 12 (8): 9848-9863. https://doi.org/10.3390/ ijerph120809848

14. Bhattacharya M., Biswas D., Sana S., Datta S. Biodegradation of waste lubricants by a newly isolated Ochrobactrum sp C1. 3 Biotech, 2015; 5: 807-817. https://doi.org/10.1007/s13205-015-0282-9

15. Ibrahim HMM. Biodegradation of used engine oil by novel strains of Ochrobactrum anthropi HM-1 and Citrobacter freundii HM-2 isolated from oilcontaminated soil. 3 Biotech, 2016; 6 (2): 226. https:// doi.org/10.1007/s13205-016-0540-5

16. Chun J., Goodfellow M. A phylogenetic analysis of the genus Nocardia with 16S rRNA gene sequencing. Int J Syst Bacteriol, 1995; 45 (2): 240-245. https://doi. org/10.1099/00207713-45-2-240

17. Husaini A., Roslan H.A., Hii K.S.Y., Ang, C H. (2008). Biodegradation of aliphatic hydrocarbon by indigenous fungi isolated from used motor oil contaminated sites. World J MicroB Biot, 2008; 24 (12): 2789-2797. https:// doi.org/10.1007/s11274-008-9806-3

18. Su W.T., Wu B.S., Chen W.J. Characterization and biodegradation of motor oil by indigenous Pseudomonas aeruginosa and optimizing medium constituents. J Taiwan Inst Chem Eng, 2011; 42 (5): 689-695. https://doi.org/10.1016/j.jtice.2011.01.002

19. Larik I.A., Qazi M.A., Kanhar A.R., Mangi S., Ahmed S., Jamali M.R., Kanhar N.A. Biodegradation of petrochemical hydrocarbons using an efficient bacterial consortium: A2457. Arab J Sci Eng. 2016; 41 (6): 2077-2086. https://doi.org/10.1007/s13369-0151851-2 